日臨外会誌 $61(10), 2757-2760,2000$

症例

急性膵炎を契機に胆道穿孔をきたした膵管胆道合流異常の 1 例

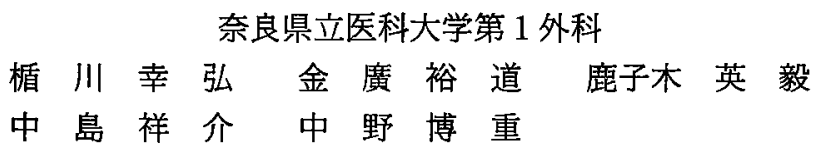

症例は 1 歳 5 カ月, 男児. 嘔吐を主訴に近医入院. 血清アミラーゼが高值であり, 腹 部エコー, CT にて膵腫大, 腹水を認め急性膵炎と診断。症状改善みられず当院へ転院と なり, 保存的治療にて血清アミラーゼは下降したが, 閉塞性黄㾝が出現した. 入院後13 日目に腹満が増強し，14日目の腹部 CT で総胆管の拡張，膵頭部の腫大，著明な腹水を 認めた。腹腔穿刺にて, 腹水中に胆汁を認め, 胆汁性腹膜炎と診断し緊急手術を施行し た. 開腹所見で, 膵上縁の胆管穿孔が疑われたが, T-tubeドレナージ術のみ行った. 術 後造影にて, 総胆管の円筒状拡張と膵管胆道合流異常を認めた。初回手術後30日目に, 胆䧶摘出術, 胆管切除, 肝管空腸吻合術を施行した。術後, 総ビリルビン, 血清アミラ 一ゼは正常化し退院となった，小児の場合，膵炎や閉塞性黄疸を主訴とした場合には， その原因として膵管胆道合流異常を念頭に入れ，胆道穿孔の危険性について配慮する必 要がある.

索引用語: 膵炎, 胆道穿孔, 膵管胆道合流異常

はじめに

小児胆道穿孔では, 嘔吐, 腹部膨満, 腹痛などの腹 膜炎症状を伴って発症し，高アミラーゼ血症がみられ ることがある，穿孔の発症機序には，膵管胆道合流異 常が強く関与していると報告されている. 今回, われ われは膵炎を契機に胆道穿孔が生じた脺管胆道合流異 常の 1 症例を経験した。

\section{症例}

症例： 1 歳 5 力月, 男児.

主訴：嘔吐.

家族歴：父方の祖父が膵癌.

現病歴と臨床経過(図 1): 平成 8 年 5 月 23日より嘔 吐を主訴とし, 自家中毒の疑いで近医入院した. 血清 アラーゼが576IU/1 と高值であり, 腹部エコー, CT で は総胆管の拡張はみられず, 軽度の膵腫大と腹水を認 め急性膵炎と診断された(図 $2 \mathrm{a}$ ). 腹腔穿刺にて, 腹 水は淡血性であり腹水中アミラーゼは4592IU/1 であ った. 症状の改善みられず，5月27日当院小児科転院

1999年10月 22 日受付 2000 年 7 月11日採用

〈所属施設住所〉

$\overline{\mathbf{T}} 634-8522$ 橿原市四条町840
となった。保存的治療にて血清アミラーゼは下降した が，閉塞性黄疸が出現した。入院後13日目より腹満の 増強がみられ，14日目の腹部 CT では総胆管の拡張， 膵頭部腫大と著明な腹水がみられた（図 2 b). 腹水検 查ではビリルビン $20.4 \mathrm{mg} / \mathrm{dl}$, アミラーゼ3369IU/1 で あり胆道穿孔による胆汁性腹膜炎と診断し緊急手術を 施行した.

入院時現症：眼球結膜に軽度の黄染を認めた。腹部 は, 腹水のため膨隆を認め, 圧痛, 腹膜刺激症状は軽 度認められた。

入院時検查所見：白血球数の増加，軽度䝪血を認め た. 総ビリルビン $3.7 \mathrm{mg} / \mathrm{dl}$, 血清アミラーゼ $395 \mathrm{IU} / 1$, CRP $1.2 \mathrm{mg} / \mathrm{dl}$ であった.

手術所見：当院入院14日目，6月10日に開腹術を施 行した. 肝十二指腸間膜前面に緑色に変色した壊死組 織を認めた。肝十二指腸間膜を剥離し検索したところ， 胆汁の流出を脺上縁の総胆管より認めたが，呀孔部を 確認修復できず T-tubeドレナージ術のみ施行した。

術後 T-tube 造影 (図 3 ) ：総胆管の円筒状拡張と, 胆管に脺管が合流する膆管胆道合流異常を認め, 共通 管は拡張していた。 T-tube 胆汁中のアミラーゼは, $31700 \mathrm{IU} / 1$ であった. また, 胆汁の細菌培養は, 陰性で 


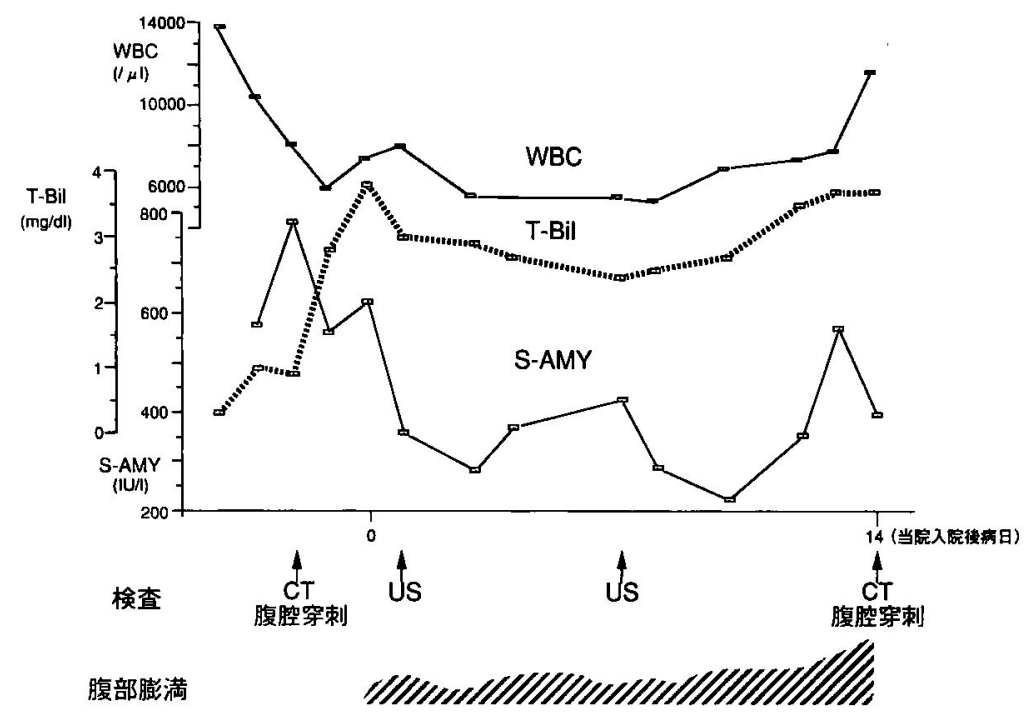

図 1 臨床経過
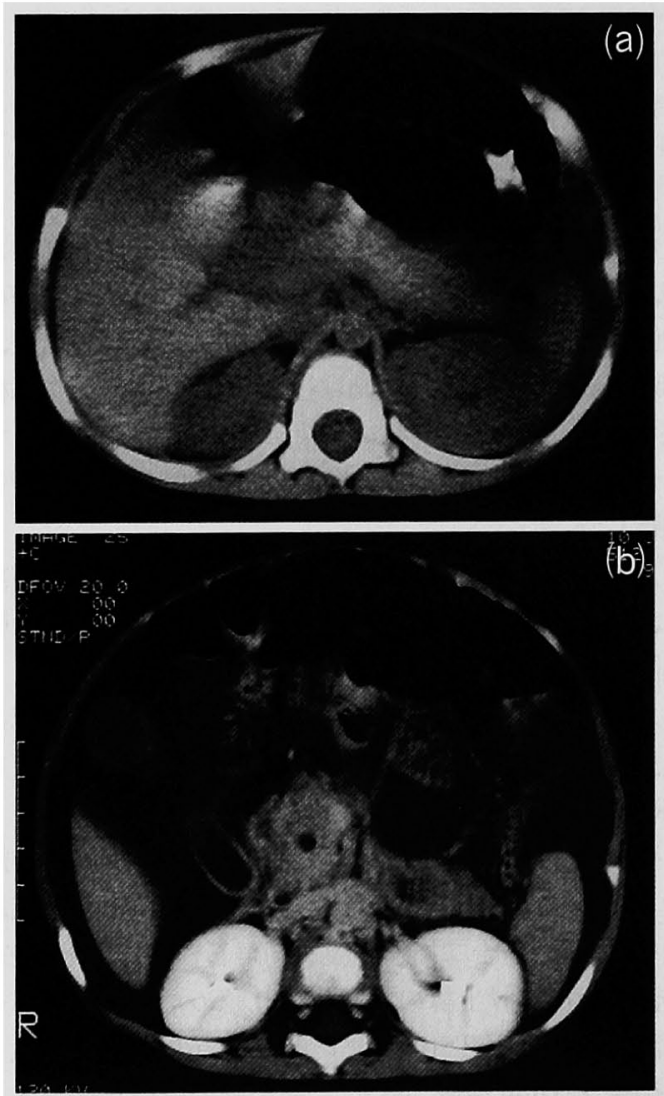

図 2 腹部 $\mathrm{CT}$

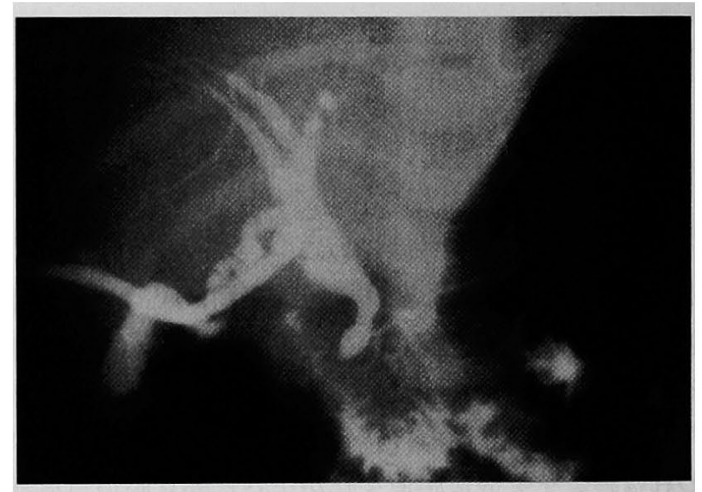

図 3 術後 T-tube 造影

あった。

膵管胆道合流異常に対し, 初回手術後30日目に, 胆 襄摘出術, 胆管切除, 肝管空腸吻合術 (Roux-en-Y 吻 合術）を施行した。

摘出固定標本および病理所見（図 4)：固定標本(a)

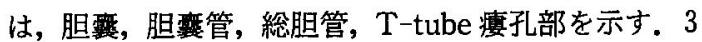
管合流部より，やや下方の総胆管に穿孔を認めた。穿 孔部の総胆管の病理所見(b)では, 悪性所見はみられず, 強い炎症を認め粘膜は多くの部分で脱落していた。

術後経過：総ビリルビン，血清アミラーゼは正常化 し，初回手術から46日目に退院となった。

$$
\text { 考察 }
$$

膵管胆道合流異常に伴う膵炎の発症機序の特徵は, 合流異常の形態としては共通管の拡張型が多く, 拡張 
部で膵液の流れが停滞しやすいためであると考えられ ている1.ささらに, 胆管内に逆流した膵酵素が活性化さ れ，膵炎を起こすか，または，胆汁が脺管内に逆流し， 脺酵素が活性化され，膵炎が発症すると考えられ $る^{2) 31}$.この膵酵素の活性化には, 感染胆汁の存在, 胆 汁酸の存在, 膵管内压の上昇が重要である2)3.

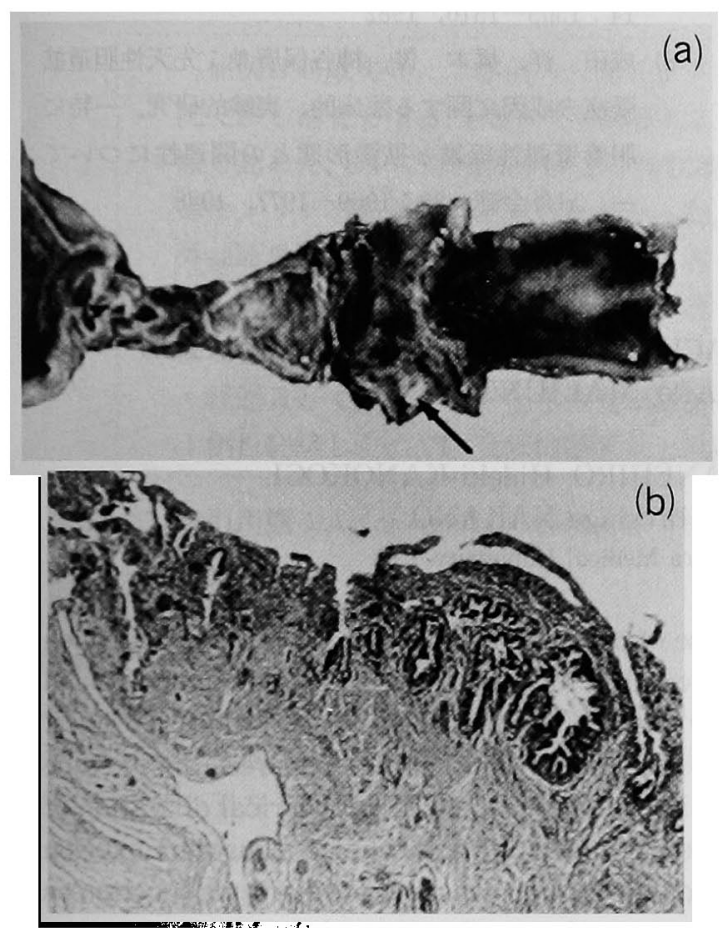

合流異常では，膵炎の症状（腹水，膵腫大など）が, なくても高アミラーゼ血症がみられることがある。そ の原因として, cholangio-venous reflux といって, 胆 斗中のアミラーゼが血液内に移行するためにおこるた めである4).

膵炎の重症度評価として，トリプシン，エラスター ゼI, ホスホリパーゼ $\mathrm{A}_{2}$, 膵分泌性トリプシン・イン ヒビター (PSTI) などがある25). 本症例では，ホスホ リパーゼ $\mathrm{A}_{2}$ と PSTI が, 血清アミラーゼの変動に応じ て変化し，膵炎の再燃を判断する指標になりうると考 えられる(図 5 )。

膵管胆道合流異常に伴う胆道穿孔の特徴として，活 性化膵醉素による胆道壁の炎症とそれに伴う壁の脆弱 化が関与していると考えられる。一般に, 胆道穿孔の 臨床像として, 年少時に多く, 胆道壁の未熟性もその 一因である(1)

本症例では，総胆管の拡張，膵頭部の腫大といった 所見から, 下部胆管, 乳頭部付近の狭窄, 閉塞による 胆道内圧の急激な上昇が加わって胆道穿孔に至ったと 推察した。

\section{まとめ}

急性萃炎を契機に，胆道穿孔をきたした膵管胆道合 流異常の 1 例を経験した.

膵炎，閉塞性黄疸を主訴とする場合，小児では，膵 管胆道合流異常の存在と胆道穿孔の危険性について考 慮しなければならない。

図 4 固定標本(a)および病理所見(b)

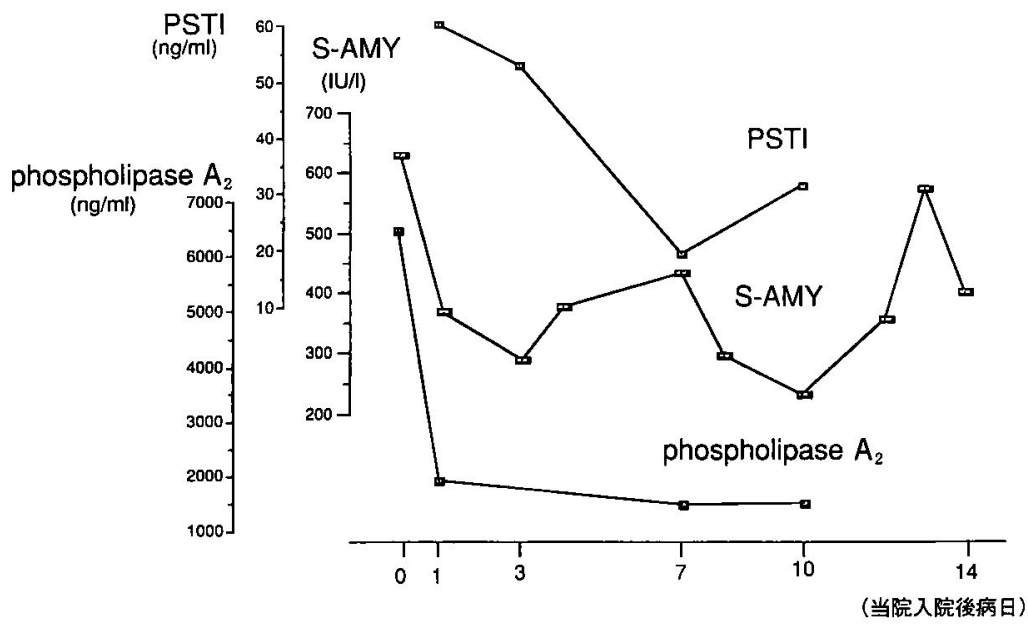

図 5 膵酵素の変化 
文献

1) 古味信彦：膵管胆道合流異常一再発見から病型分 類まで一。臨外医会誌 $53: 481-497,1992$

2）中村哲郎：膵管胆道合流異常における膵炎の発生 に関する実験的研究一萃 Phospholipase $\mathrm{A}_{2}$ の活 性化を中心に一。 日外会誌 $95 ： 382-393 ， 1994$

3）宮野 武, 須田耕一：膵管胆道合流異常と脺合併 症. 古味信彦編, 消化器病セミナー 27 , 膵管胆道 合流異常, へるす出版，東京. 1987, p88-104

4）大川治夫, 澤口重徳, 山崎洋次他: 膵管胆道合流 異常における高アミラーゼ血症の発生機序に関す る実験的検討. 日小児外会誌 $19: 21-26,1983$

5）小川道雄：膵分泌性トリプトシン・インヒビター
(PSTI). 日臨（上巻） 53 (増刊号)：317-322, 1995

6）矢野博道，高宮紘士，满手博義他：小児の特発性 胆道穿孔の臨床的愉討. 小児外科 $9: 1180-$ 1190,1977

7）高見 宏, 岡田 正, 大口善郎他：膵管胆道合流 異常を伴った特発性胆道穿孔の 2 例. 小坚外科 $14: 1505-1510,1982$

8）成田 洋, 橋本 俊, 神谷保廣他：先天性胆道拡 張症の成因に関する臨床的, 実験的研究. 一特に 胆管壁弾性線維と拡張形態との関連性について 一. 日外会誌 $89: 1969-1977,1988$

\title{
PERFORATED BILE DUCT IN A CASE OF ACUTE PANCREATITIS ASSOCIATED WITH PANCREATICOBILIARY MALJUNCTION
}

\author{
Yukihiro TATEKAWA, Hiromichi KANEHIRO, Hideki KANOKOGI, \\ Yoshiyuki NAKAJIMA and Hiroshige NAKANO \\ First Department of Surgery, Nara Medical University
}

A 1 year and 5 month-old male was admitted because of pancreatitis. US and CT showed a swollen pancreas and ascites. Although conservative therapy decreased the serum amylase value, jaundice and abdominal distension appeared. The fluid obtained by intraabdominal puncture revealed bile juice. Emergent operative findings disclosed a perforated bile duct on the upper of the pancreas and T-tube drainage was carried out. Cholangiography conducted via the $T$-tube showed cylinderical dilatation of the common bile duct and pancreaticobiliary maljunction. Cholecystectomy, choledochus duct excison and hepaticojejunostomy were performed. Physicians should consider pancreaticobiliary maljunction as a cause of pancreatitis and obstructive jaundice, and recognize that perforation of the bile duct can be associated with this condition. Key words : pancreatitis, pancreaticobiliary maljunction. 